\title{
PERSFEKTIF ISLAM TENTANG KEDUDUKAN DAN PERANAN GURU DALAM PENDIDIKAN
}

\author{
Arfandi \\ Universitas Ibrahimy Situbondo \\ Email: arfandi.1985@gmail.com
}

\begin{abstract}
A teacher is someone who provides knowledge to their students and is responsible for educating, teaching, guiding, directing, assessing and evaluating their students so that it is useful in the future. Professional teachers are teachers who are able to apply multidimensional relationships. Such teachers are those who internally have four competencies, namely: pedagogical competence, professional competence, personality competence, and social competence. The Islamic perspective on the position and role of the teacher is to position the teacher or educator in a noble position. Educators are positioned as spiritual fathers (spiritual father) for their students. He provides spiritual food with knowledge and development of noble morals (akhlaqalkarimah) and straightens them out. To create educators who are professional as well as competent in Islamic education, it is based on the demands of the Prophet because he was the only most successful educator in a short span of time, so that it is hoped that he can get closer to the reality of the educator with the ideal (Prophet Saw). The following are the competencies of Islamic educators and education: Religious Personal Competencies, Religious Social Competencies and Religious Professional Competencies.
\end{abstract}

Keywords: Islamic perspective, position, teacher's role

\begin{abstract}
Abstrak
Guru adalah seseorang yang memberikan ilmu pengetahuan kepada anak didiknya dan bertanggung jawab untuk mendidik, mengajar, membimbing, mengarahkan, menilai dan mengevaluasi anak didiknya agar bermanfaat dimasa yang akan datang. Guru profesional yaitu guru yang mampu menerapkan hubungan yang berbentuk multidimensional. Guru yang demikian adalah yang secara internal memiliki empat kompetensi, yaitu: kompetensi pedagogik, kompetensi profesional, kompetensi kepribadian, dan kompetensi sosial. Perfektif Islam tentang kedudukan dan perananan guru adalah memposisikan guru atau pendidik pada kedudukan yang mulia. Para pendidik diposisikan sebagai bapak ruhani (spiritual father) bagi anak didiknya. Ia memberikan santapan ruhani dengan ilmu dan pembinaan akhlak mulia (akhlaqalkarimah) dan meluruskannya. Untuk mewujudkan pendidik yang professional sekaligus yang berkompeten dalam pendidikan Islam, didasari dari tuntutan Nabi Saw karena beliau satusatunya pendidik yang paling berhasil dalam rentang waktu yang singkat, sehingga diharapkan dapat mendekatkan realitas pendidik dengan yang ideal (Nabi Saw). Berikut ini adalah kompetensi pendidik dan pendidikan Islam : Kompetensi Personal Religius, Kompetensi Sosial Religius dan Kompetensi Profesional Religius.
\end{abstract}

Kata Kunci: Presfektif Islam, Kedudukan, Peran Guru 


\section{A. Pendahuluan}

Kedudukan guru sebagai seorang pendidik di masyarakat benar-benar sangat dihormati dan dihargai, masyarakat tidak meragukan lagi terhadap sosok seoarang guru yang memiliki kharisma dan kebiwaan yang ada pada diri seorang guru. Kepercayaan masyarakat sangat meningkat terhadap keberadaan guru yang diyakininya akan memberikan dampak yang positif dalam pembentukan pendidikan karakter atau keperibadian anak didik, sehingga anak didik akan menjadi manusia yang berguna dengan memiliki intelektual yang mempuni serta memiliki jiwa kepemimpinan yang baik sehingga nantinya bisa menjalani tugas sebagai pemimpin yang penuh rasa tanggungjawab terhadap tugas yang diembannya. Oleh karena itu, secara sederhana dapat diberikan pemahaman bahwa seorang guru merupakan sosok yang bisa mentransfer ilmu pengetahuan dan juga bisa memberikan bimbingan dan arahan terhadap anak didik. Sedangkan masyarakat mempunyai pandangan bahwa seorang guru adalah seseorang yang memiliki tugas dalam melaksanakan kegiatan belajar mengajar di tempat-tempat yang sudah ditentukan, tidak hanya bertempat di lembaga pendidikan formal saja akan tetapi juga di dalam lembaga pendidikan yang non formal seperti di dalam masjid, mushollah, lapangan dan rumah.

Bagi seorang guru sudah pasti harus memiliki ciri khas, kharisma dan juga memilki akhlakul karimah yang menjadi teladan bagi anak didik. Tugas guru sangat komplit disatu sisi seorang guru tentu memilki rasa sabar, ramah, serta mampu menciptakan keperyaan bagi anak didik, akan tetapi disisi lain seorang guru tentu juga bisa membantu anak didik untuk mencapai cicta-citanya disamping itu pula guru memberikan bimbingan, arahan, serta memberikan penilaian terhadap keberhasilan yang dikerjakan oleh anak didik.

Guru adalah memiliki tugas dan tanggungjawab serta mempunyai sebutan sebagai profesi, maka sudah barang tentu seorang guru harus memiliki dan mengembangkan kompetensi guna untuk menjadi guru yang professional yang sesuai dengan tuntutan zaman dan dinamika perkembangan teknologi dan ilmu pengetahuan. Tugas seorang guru tidak hanya sebagai pendidik, akan tetapi tugas guru juga bisa mengajar, dan melatih anak didik semua tugas dan ntanggungjawab itu menjadikan guru sebagai suatu profesi yang bagi dirinya. Oleh karena itu, bila 
melihat tugas yang dimiliki oleh guru sebagai seorang pendidik, tentu hal itu seorang guru akan terus untuk mengembangkan potensi-potensi yang dimiliki oleh anak didik. Selain itu tugas seorang guru juga sebagai pengajar dengan tugas sebagai pengajar tersebut tentu seorang guru harus bisa memberikan dan mengembangkan keilmuan terhadap anak didik. Selain tugas sebgai pendidik, pengajara dan pelatih seorang guru dituntut untuk memiliki keahlian yang sesuai dengan profesi yang melekat pada guru. Dengan demikian, kedudukan dan peranan guru dalam pendidikan sangat membantu dalam mengarahkan dan membimbing anak didik untuk menjadikan anak didik khoiroh ummat, berakhlak mulia, serta beriman dan bertakwa. Dalam artikel ini akan mengurai dan membahas secara mendalam bagai pandangan Islam terhdap kedudukan dan peranan seorang guru dalam menjalankan tugasanya dalam pendidikan.

\section{B. Landasan Teori}

\section{Pengertian dan Fungsi Guru dalam Pendidikan}

Definisi Guru versi Kamus Besar Bahasa Indonesia, yaitu orang yang menjadi aktivitas/profesi sebagai mengajar. Sedangkan definisi versi Undang-Undang Sisdiknas Nomor 20 Tahun 2003 pasal 39, dikatakan bahwa Pendidik adalah merupakan tenaga profesional yang mempunyai tugas untuk merencanakan dan melaksanakan proses pembelajaran, menilai hasil pembelajaran serta melakukan penelitian dan pengabdian kepada masyarakat, terutama bagi pendidik pada perguruan tinggi. Menurut Undang-undang Nomor 14 tahun 2005 Guru adalah pendidik profesional dengan tugas utama sebagai pendidik, pengajar, pembimbing, mengarahkan, melatih, menilai, dan mengevaluasi peserta didik pada pendidikan anak usia dini jalur pendidikan formal, pendidikan dasar, dan pendidikan menengah.

Sedangkan pengertian guru versi Nor Jamaluddin (1978:1) adalah sebagai pendidik, yaitu orang yang sudah dewasa mempunyai tanggungjawab dalam mengarahkan dan bimbingan kepada anak didik agar secara rohani dan jasmai berkembang sehingga anak didik bisa melaksanakan tugasnya di muka bumi ini dengan baik. 
Pengertian guru bila dipandang secara etimologis, adalah merupakan salah satu yang sering disebut dengan sebutan pendidik. Sedangkan jika dilihat pengertian dalam bahasa arab, ada beragam pengertrtian yang menunjukkan arti profesi ini seperti, mudarris, mua'allim, murabbi dan mu'addib, yang meski memiliki makna yang sama, namun masing-masing mempunyai karakteristik yang berbeda. Disamping kata-kata tersebut, juga sering digunakan kata ustadz atau syaikh. Penyebutan ini tidak terlepas dari rekomendasi Konferensi Pendidikan Internasional di Makkah pada tahun 1977, yang antara lain merekomendaikan bahwa pengertian pendidikan mencakup tiga pengertian, yaitu tarbiyah, ta'lim dan ta'dib. Maka pengertian guru atau pendidik mencakup murabbi, mu'allim dan mu'addib (Muhaimin dan Abdul Mujib, 1993:164).

Pengertian Murabbi mengisyaratkan bahwa guru adalah orang yang memiliki sifat rabbani, artinya orang yang bijaksana, bertanggungjawab, berkasih sayang terhadap siswa dan mempunyai pengetahuan tentang rabb. Dalam pengertian mu'allim, ia mengandung arti bahwa guru adalah orang berilmu yang tidak hanya menguasai ilmu secara teoretik tetapi mempunyai komitmen yang tinggi dalam mengembangkan ilmu yang dimilikinya. Sedangkan dalam konsep $t a$ 'dib, terkandung pengertian integrasi antara ilmu dan amal sekaligus (Muhaimin dan Abdul Mujib, 1993:164).

Secara terminologi, guru sering diartikan sebagai orang yang bertanggungjawab terhadap perkembangan siswa dengan mengupayakan perkembangan seluruh potensi (fithrah) siswa, baik potensi kignitif, potensi apektif, maupun potensi psikomotorik (Ramayulis, 2004: 86). Guru juga berarti orang dewasa yang bertanggung jawab memberikan pertolongan pada siswa dalam perkembangan jasmani dan rohaninya agar mencapai tingkat kedewasaan, mampu berdiri sendiri memenuhi tugasnya sebagai hamba ('abd) dan khalifah Allah (khalifatullah) dan mampu sebagai makhluk sosial dan sebagai makhluk individual yang mandiri (Ahmad Zayadi, 2005:25).

Peran dan fungsi yang cukup berat untuk diemban ini tentu saja membutuhkan sosok seorang guru atau pendidik yang utuh dan tahu dengan kewajiban dan tanggung jawab sebagai seorang pendidik. Pendidik itu harus 
mengenal Allah Swt. dalam arti yang luas dan Rasul serta memahami risalah yang dibawanya serta mengamalkannya. Fungsi guru, yaitu :

1. Sebagai Pengajar (instruksional) yang bertugas merencanakan program pengajaran dan melaksanakan program yang telah disusun dan penilaian setelah program itu dilaksnakan.

2. Sebagai Pendidik (edukator) yang mengarahkan peserta didik pada tingkat kedewasaan yang berkepribadian insan kamil, seiring dengan tujuan Allah Swt. menciptakan manusia.

3. Sebagai Pemimpin (managerial) yang memimpin dan mengendalikan diri sendiri, peserta didik dan masyarakat yang terkait. Menyangkut upaya pengarhan, pengawasan, pengorganisasian, pengontrolan, partisipasi atas program yang dilakukan itu.

4. Sebagai Pembimbing yang membimbing berdasarkan pengetahuan dan pengalamannya bertanggung jawab atas kelancaran perjalanan itu.

5. Sebagai Model dan Teladan bagi para peserta didik dan semua orang yang menganggap dia sebagai guru.

6. Sebagai administrator pada bidang pendidikan dan pengajaran.

7. Sebagai Penasehat bagi peserta didik juga bagi orang tua, meskipun mereka tidak memiliki latihan khusus sebagai penasehat dan dalam beberapa hal tidak dapat berharap untuk menasehati orang.

8. Sebagai Pembaharu (Inovator) yang menerjemahkan pengalaman dan telah larut ke dalam kehidupan yang bermakna bagi peserta didik.

9. Sebagai Emansipator yang mampu memahami potensi peserta didik, menghormati setiap insan dan menyadari bahwa kebanyakan insan merupakan "budak" stagnasi kebudayaan.

10. Sebagai Evaluator atau penilaian yang merupakan aspek pembelajaran yang paling kompleks, karena melibatkan banyak latar belakang dan hubungan, serta variable lain yang mempunyai arti apabila berhubungan dengan konteks yang hampir tidak mungkin dapat dipisahkan dengan setiap segi penilaian.

11. Sebagai Kulminator yang mengarahkan proses belajar secara bertahap dari awal hingga akhir (kulminasi). 
12. Sebagai Anggota Masyarakat yang diharapkan dapat berperan aktif dalam pembangunan disegala bidang yang sedang dilakukan.

13. Sebagai Pendorong Kreatifitas yang sangat penting dalam pembelajaran dan guru dituntut untuk mendemonstrasikan dan menunjukkan proses kreatifitas tersebut.

\section{Kedudukan dan Fungsi Guru Menurut Ajaran Islam}

Agama Islam memposisikan guru atau pendidik pada kedudukan yang mulia. Para pendidik diposisikan sebagai bapak ruhani (spiritual father) bagi anak didiknya. Ia memberikan santapan ruhani dengan ilmu dan pembinaan akhlak mulia (akhlaqalkarimah) dan meluruskannya. Oleh karena itu, pendidik mempunyai kedudukan yang sangat tinggi, bahkan tinta seorang alim (guru) lebih berharga dari pada darah para syuhada. Keutamaan seorang guru atau pendidik disebabkan oleh tugas mulia yang diembannya. Tugas yang diemban guru (dalam ajaran islam) hampir sama dengan tugas seorang Rasul. Hal ini, misalnya, tertera dalam sebuah syair karya Syauqi: Berdiri dan hormatilah guru dan berdirilah penghargaan, seorang guru itu hampir saja merupakan seorang Raasul (AlAbrasy, 1987:135).

Guru adalah bapak rohani (spiritual father) bagi peserta didik yang memberikan santapan jiwa dengan ilmu, pembinaan akhlak mulia, dan meluruskan perilaku buruknya. Oleh karena itu, pendidik mempunyai kedudukan yang tinggi dalam islam. Dijelasakan dalam hadits Nabi: "Tinta seorang ilmuan (yang menjadi guru) lebih berharga dari pada darah pada syuhadah”. Bahkan Islam menempatkan guru setingkat dengan derajat rosul, seperti tertulis pada syairnya Al-Syawki: "Berdiri dan hormatilah guru dan berilah penghargaan, seorang guru itu hampir saja merupakan seorang rasul”. Pendapat lain menjelaskan:

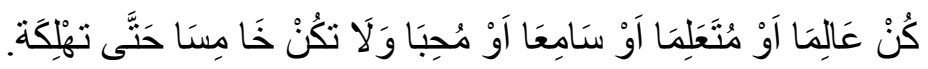

Artinya:"Jadilah engkau sebagai guru, atau pelajar, atau pendengar, atau pecinta dan janganlah kamu menjadi orang yang kelima, sehingga engkau menjadi rusak".

Al-Ghazali menegaskan bahwa kedudukan yang tinggi yang diduduki oleh orang yang berpengetahuan bahwa orang alim yang bersedia mengamalkan 
pengetahuannya adalah orang besar disemua kerajaan langit, dia seperti matahari yang menerangi alam, ia mempunyai cahaya dalam dirinya seperti minyak wangi yang mengharumi orang lain karena ia memang wangi. Dijelaskan pada QS. AlMujadilah:11.

Artinya:"Hai orang-orang beriman apabila kamu dikatakan kepadamu: "Berlapang-lapanglah dalam majlis", Maka lapangkanlah niscaya Allah akan memberi kelapangan untukmu. dan apabila dikatakan: "Berdirilah kamu", Maka berdirilah, niscaya Allah akan meninggikan orang-orang yang beriman di antaramu dan orang-orang yang diberi ilmu pengetahuan beberapa derajat. dan Allah Maha mengetahui apa yang kamu kerjakan".

Dari pandangan itu, dipahami bahwa tugas guru merupakan pewaris Nabi (warasat alanbiya), yang pada hakikatnya mengemban misi rahmatan lil'alamin (membawa rahmat bagi seluruh alam), yakni suatu misi yang mengajak manusia untuk tunduk dan patuh pada hukum-hukum Allah guna memperoleh keselamatan dunia dan akhirat. Kemudian misi ini dikembangkan kepada pembentukan kepribadian yang berjiwa tauhid, kreatif, beramal sholeh dan bermoral tinggi.

Untuk melaksnakan tugas sebagai warasatulanbiya, gur hendaklah bertolak pada amar ma'ruf (memerintah kepada yang baik) yang diimbangi dengan nahi an almunkar (mencegah kemunkaran/kejelekan), menjadikan prinsip tauhid sebagai pusat kegiatan penyebaran misi Iman, Islam dan Ihsan. Dengan demikian, menurut Alghazali, tugas utama guru adalah menyempurnakan, membersihkan dan menyucikan hati manusia untuk mendekatkan diri kepada Allah. Sejalan dengan pendapat ini, AnNahlawi mengatakan bahwa ada dua tugas utama guru, yaitu pertama, fungsi penyucian, yakni berfungsi sebagai pembersih, pemelihara dan pengembang fitrah manusia. Kedua, fungsi pengajaran, yakni menginternalisasikan kepada manusia.

Pendapat lain mengemukakan bahwa fungsi pendidik yaitu, pertama pensucian artinya sebagai pemelihara diri, pengembang serta pemeliharaan fitrah manusia, kedua adalah fungsi pengajaran artinya sebagai penyampai ilmu pengetahuan dan berbagai keyakinan kepada manusia agar mereka menerapkan seluruh pengetahuan dalam kehidupan seharihari. Maka dari itu, peran pendidikan sangat berperan penting dalam proses pendidikan, karena 
dia yang bertanggung jawab dan menentukan arah pendidikan tersebut. Maka, itulah sebabnya Islam sangat menghargai dan menghormati orang-orang yang berilmu pengetahuan dan bertugas sebagai pendidik yang mempunyai tugas yang sangat mulia (Basuki dan Ulum, 2007:881).

\section{Kompetensi Guru Menurut UU No. 14 Tahun 2005}

Menurut Undang-undang Nomor 14 Tahun 2005 tentang Guru dan Dosen, kompetensi adalah seperangkat pengetahuan, keterampilan, dan perilaku yang harus dimiliki, dihayati, dan dikuasai oleh guru atau dosen dalam melaksanakan tugas keprofesionalan. Kompetensi merupakan syarat yang harus dimiliki guru agar dapat melaksanakan tugas dengan profesional sehingga mencapai tujuan pembelajaran secara efektif dan efisien.

Kompetensi dalam Bahasa Indonesia merupakan serapan dari bahasa Inggris, competence yang berarti kecakapan dan kemampuan (Musfah, 2015:27). Kompetensi adalah kumpulan pengetahuan, perilaku, dan keterampilan yang harus dimilki guru untuk mencapai tujuan pembelajaran dan pendidikan. Kompetensi berarti kemampuan mewujudkan sesuatu sesuai dengan tugas yang diberikan kepada seseorang. Kompetensi juga terkait dengan standar dimana seseorang dikatakan kompeten dalam bidangnya jika pengetahuan, keterampilan, dan sikap serta hasil kerjanya sesuai standar (ukuran) yang ditetapkan dan/atau diakui oleh lembaganya/pemerintah. Musfah (2015:27) hakikat kompetensi adalah kekuatan mental dan fisik untuk melakukan tugas atau keterampilan yang dipelajari melalui latihan dan praktek. Dari hal ini maka suatu kompetensi dapat diperoleh melalui pelatihan dan pendidikan.

Pengertian kompetensi guru berdasarkan Undang-undang Nomor 14 Tahun 2005 adalah kompetensi guru dapat dimaknai sebagai kebulatan pengetahuan, keterampilan dan sikap yang berwujud tindakan cerdas dan penuh tanggung jawab dalam melaksanakan tugas sebagai agen pembelajaran. Menurut Mulyasa (2013:27) Kompetensi guru merupakan perpaduan antara kemampuan personalia, keilmuan, teknologi, sosial, dan spiritual yang membentuk kompetensi standar profesi guru, yang mencakup penguasaan materi, pemahaman terhadap peserta didik, pembelajaran yang mendidik, pengembangan pribadi dan profesionalitas. Kompetensi guru lebih merujuk pada kemampuan guru untuk mengajar dan 
mendidik sehingga menghasilkan perubahan perilaku belajar dari peserta didik. Kemampuan guru yang dimaksud adalah tidak hanya dari segi pengetahuan saja tetapi juga dari segi kepribadian, sosial dan profesional sebagai guru.

\section{Kompetensi Pedagogik}

Guru sebagai seseorang yang berwenang untuk mengajar dan mendidik peserta didik agar dapat mencapai keberhasilan di masa depan maka guru harus bisa memberikan apa yang dibutuhkan peserta didik dalam proses pembelajaran sesuai dengan karakteristik peserta didik. Siswoyo (2013:118) mengemukakan bahwa kompetensi pedagogik itu bukan hanya bersifat teknis belaka, yaitu "kemampuan mengelola pembelajaran kelas ..." (yang dirumuskann dalam PP RI No. 19 Tahun 2005. Kompetensi pedagogik tidak hanya mencakup perencanaan, pelaksanaan dan penilaian pembelajaran namun juga menguasai ilmu pendidikan. Ilmu pendidikan diperlukan karena seorang guru haarus mengetahui wawasan tentang pendidikan yang ada sehingga guru dapat mempersiapkan strategi yang efektif dan efisien yang sebaiknya digunakan. Menurut Musfah (2015:30) kompetensi pedagogik adalah kemampuan dalam pengelolaan peserta didik yang meliputi 1) pemahaman wawasan atau landasan kependidikan; 2) pemahaman tentang peserta didik; 3) pengembangan kurikulum atau silabus; 4) perancangan pembelajaran; 5) pelaksanaan pembelajaran yang mendidik dan dialogis; 6) evaluasi hasil belajar; dan 7) pengembangan peserta didik untuk mengaktualisasikan berbagai potensi yang dimilikinya.

Kompetensi pedagogik merupakan syarat yang harus dimiliki oleh seorang guru. Kompetensi pedagogik diperlukan guru untuk berinteraksi dengan siswa pada saat pembelajaran, mulai dari tahap perencanaan, pelaksanaan, evalasi hingga tindak lanjut dari suatu pembelajaran. Apabila guru tidak bisa menguasi kompetensi pedagogik maka akan mengalami permasalahan dalam pembelajaran.

\section{Kompetensi Kepribadian}

Konsep Kompetensi KepribadianDalam jurnal Pengembangan Kepribadian Guru menurut Nursyamsi (2014) dalam Kartono (2005:9) menjelaskan bahwa kepribadian itu secara langsung berhubungan dengan kapasitas psikis seseorang; berkaitan dengan nilai-nilai etis atau kesusilaan dan tujuan hidup. Kepribadian itu manusia itu juga selalu mengandung unsur dinamis, yaitu ada kemajuan-kemajuan 
atau progress menuju suatu integrasi baru tapi system psikofisis tersebut tidak pernah akan sempurna bisa terintegrasi dengan sempurna. Kepribadian ini mencakup kemampuan adaptasi (menyesuaikan diri) yang karakteristik terhadap lingkungan."Dalam Standar Nasional Pendidikan, penjelasaan pasal 28 ayat (3) butir b, dikemukakan bahwa yang dimaksud dengan kompetensi kepribadian adalah kemampuan kepribadian yang mantap, stabil, dewasa, arif, dan berwibawa, mejadi teladan bagi peserta didik, dan berakhlak mulia" (Mulyasa, 2013:117).

Kompetensi kepribadian memiliki andil yang sangat besar bagi pembentukkan kepribadian dan karakter peserta didik. Dalam pendidikan, guru menjadi sosok yang paling penting dalam membentuk kepribadian siswa, karena manusia memiliki naluri untuk mencontoh orang lain. Maka secara tidak langsung ketika guru seorang guru semakin dekat dengan siswanya maka semakin besar kemungkinan siswa tersebut akan mencontoh kepribadian guru tersebut. Sehubungan dengan uraian tersebut maka setiap guru dituntut untuk memiliki kompetensi yang baik dan memadai agar dapat membentuk kepribadian peserta didik menjadi baik. Selain itu, kompetensi kepribadian juga menjadi landasan terhadap kompetensi-kompetensi lainnya. Guru sebagai pendidik tidak hanya mentransfer ilmu tetapi juga harus membentuk kepribadian siswa menjadi individu yang baik.

\section{Kompetensi profesional}

Konsep Profesional Dalam jurnal Meningkatkan Profesionalisme Guru: Sebuah Harapan (Ali Muhson, 2004) Profesionalisme merupakan paham yang mengajarkan bahwa setiap pekerjaan harus dilakukan oleh orang yang profesional. Orang yang professional itu sendiri adalah orang yang memiliki profesi. Muchtar Luthfi (1984:44) menyebutkan bahwa seseorang disebut memiliki profesi bila ia memenuhi kriteria sebagai berikut:

1. Profesi harus mengandung keahlian, artinya suatu profesi itu mesti ditandai oleh suatu keahlian yang khusus untuk profesi itu. Keahlian itu diperoleh dengan cara mempelajari secara khusus karena profesi bukanlah sebuah warisan. 
2. Profesi dipilih karena panggilan hidup dan dijalani sepenuh waktu. Profesi juga dipilih karena dirasakan sebagai kewajiban sepenuh waktu, maksudnya bukan bersifat part time.

3. Profesi memiliki teori-teori yang baku secara universal. Artinya, profesi itu dijalani menurut aturan yang jelas, dikenal umum, teori terbuka dan secara universal pegangannya itu diakui.

4. Profesi adalah untuk masyarakat, bukan untuk diri sendiri.

5. Profesi harus dilengkapi dengan kecakapan diagnostik dan kompetensi aplikatif. Kecakapan dan kompetensi itu diperlukan untuk meyakinkan peran profesi itu terhadap kliennya.

6. Pemegang profesi memiliki otonomi dalam melakukan tugas profesinya. Otonomi ini hanya dapat diuji atau dinilai oleh rekan-rekannya seprofesi.

7. Menurut Badan Standar Nasional Pendidikan (2006:88) dalam buku Peningkatan Kompetensi Guru Melalui Pelatihan dan Sumber Belajar Teori dan Praktik (Musfah, 2015:54) kompetensi professional adalah: "Kemampuan penguasaan materi pembelajaran secara luas dan mendalam meliputi; 1) konsep, struktur, dan metode keilmuan/teknologi/seni yang menaungi/koheren dengan materi ajar; 2) materi ajar yang ada dalam kurikulum sekolah; 3) hubungan konsep antar mata pelajaran terkait; 4) penerapan konsep keilmuan dalam kehidupan sehari-hari; dan 5) kompetensi secara profesional dalam konteks global dengan tetap melestarikan nilai budaya nasional".

\section{Kompetensi sosial}

Membaca kata "sosial" membuat pikiran terarah kepada suatu hubungan. Hubungan yang dimaksud ialah kemampuan seseorang untuk melakukan interaksi dengan orang lain dimana hal tersebut menandakan bahwa manusia merupakan makhluk sosial yang tidak dapat hidup sendiri. Sehingga manusia dijuluki dengan zoon politicon dimana setiap manusia pasti membutuhkan bantuan orang lain dalam setiap kegiatan. Berkaitan dengan pendidikan, aspek sosial ini sangat diperlukan dalam kompetensi seorang guru, karena di era abad ke- 21 nanti guru dituntut lebih cakap dalam berkomunikasi baik dengan peserta didik ataupun orang tua/ wali. Kemampuan berkomunikasi ini masuk dalam kompetensi guru 
yaitu kompetensi sosial. Menurut Siswoyo (2013) kompetensi sosial adalah kemampuan yang harus dimiliki oleh pendidik di sekolah untuk berkomunikasi dan berinteraki secara efektif dan efisien dengan peserta didik, sesama guru, orangtua/ wali peserta didik, dan masyarakat sekitar. Kompetensi ini diukur dengan portofolio kegiatan, prestasi dan keterlibatan dalam berbagai aktivitas. Sedangkan dalam Standar Nasional Pendidikan Pasal 28 ayat (3) butir d dikemukakan pengertian kompetensi sosial adalah kemampuan guru sebagai bagian dari masyarakat untuk berkomunikasi dan bergaul secara efektif dengan peserta didik, sesama pendidik, tenaga pendidikan, orang tua/wali peserta didik, dan masyarakat sekitar. Kompetensi sosial yang dimiliki guru minimal memiliki kemampuan untuk 1) Berkomunikasi secara lisan, tulisan, maupun isyarat, 2) Mengoperasikan teknologi komunikasi dan informasi, 3) Bergaul secara efektif dan efisien, 4) Bergaul yang sesuai dengan nilai norma masyarakat

Menurut Abduhzen dalam Mulyasa (2009:174) mengungkapakan bahwa: Imam Al- Ghazali menempatkan profesi guru pada posisi tertinggi dan termulia dalam berbagai tingkat pekerjaan dalam masyarakat. Guru dalam pandangan AlGhazali mengemban dua misi sekaligus, yaitu tugas keagamaan, ketika guru melakukan kebaikan dengan menyampaikan ilmu pengetahuan kepada manusia sebagai makhluk termulia di muka bumi ini. Sedangkan yang termulia dalam tubuh manusia adalah hatinya. Guru bekerja menyempurnakan, membersihkan, menyucikan, dan membawakan hati itu mendekat Allah Azza wa Jalla. Kedua tugas sosiopolitik (kekhalifahan), dimana guru membangun, memimpin, dan menjadi teladan yang menegakan keteraturan, kerukunan, dan menjamin keberlangsungan masyarakat, yang keduanya berujung pada pencapaian kebahagiaan akhirat. Oleh karena itu guru harus memiliki standar kualitas pribadi tertentu, yang mencakup tanggung jawab, wibawa, mandiri, dan disiplin.

\section{Metode Penelitian}

Metode yang digunakan dalam penelitian ini dengan menggunakan jenis kualitatif yaitu mendeskripsikan dan memaparkan informasi atau data yang tidak berbentuk angka atau kuantitatif. Adapun teknik pengumpulan data yang digunakan dalam metode kualitatif ini dengan cara menggunakan studi pustaka 
yaitu mencari dan mengumpulkan data-data atau informasi-informasi terkait tema dari literatur, baik berbentuk buku-buku atau kitab-kitab, laporan-laporan, catatancatatan, majalah, Koran dan lainnya. Sedangkan analisisnya menggunakan analisis historis yang menjadikan peristiwa sebagai objek mengapa bisa terjadi agar hasil yang ditemukan bermanfaat sebagai pertimbangan dan bahan dalam pengembangan pendidikan.

\section{Hasil}

Hasil temuan menunjukkan tentang persfektif Islam tentang kedudukan dan peranan guru dalam pendidikan adalah bahwa Agama Islam memposisikan guru atau pendidik pada kedudukan yang mulia. Para pendidik diposisikan sebagai bapak ruhani (spiritual father) bagi anak didiknya. Ia memberikan santapan ruhani dengan ilmu dan pembinaan akhlak mulia (akhlaqalkarimah) dan meluruskannya. Oleh karena itu, pendidik mempunyai kedudukan yang sangat tinggi, bahkan tinta seorang alim (guru) lebih berharga dari pada darah para syuhada. Keutamaan seorang guru atau pendidik disebabkan oleh tugas mulia yang diembannya. Tugas yang diemban guru (dalam ajaran Islam) hampir sama dengan tugas seorang Rasul. Hal ini, misalnya, tertera dalam sebuah syair karya Syauqi: Berdiri dan hormatilah guru dan berdirilah penghargaan, seorang guru itu hampir saja merupakan seorang Raasul.

\section{E. Pembahasan}

Guru adalah bapak rohani (spiritual father) bagi peserta didik yang memberikan santapan jiwa dengan ilmu, pembinaan akhlak mulia, dan meluruskan perilaku buruknya. Oleh karena itu, pendidik mempunyai kedudukan yang tinggi dalam islam. Dijelasakan dalam hadits Nabi: "Tinta seorang ilmuan (yang menjadi guru) lebih berharga dari pada darah pada syuhadah”. Bahkan Islam menempatkan guru setingkat dengan derajat rosul, seperti tertulis pada syairnya Al-Syawki: "Berdiri dan hormatilah guru dan berilah penghargaan, seorang guru itu hampir saja merupakan seorang rasul”. Pendapat lain menjelaskan:

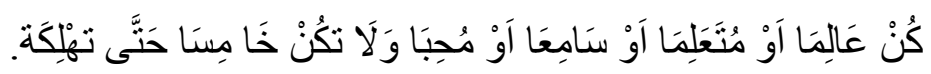


Artinya:"Jadilah engkau sebagai guru, atau pelajar, atau pendengar, atau pecinta dan janganlah kamu menjadi orang yang kelima, sehingga engkau menjadi rusak".

Al-Ghazali menegaskan bahwa kedudukan yang tinggi yang diduduki oleh orang yang berpengetahuan bahwa orang alim yang bersedia mengamalkan pengetahuannya adalah orang besar disemua kerajaan langit, dia seperti matahari yang menerangi alam, ia mempunyai cahaya dalam dirinya seperti minyak wangi yang mengharumi orang lain karena ia memang wangi. Dijelaskan pada QS. AlMujadilah:11.

Artinya: "Hai orang-orang beriman apabila kamu dikatakan kepadamu: "Berlapang-lapanglah dalam majlis", Maka lapangkanlah niscaya Allah akan memberi kelapangan untukmu. dan apabila dikatakan: "Berdirilah kamu", Maka berdirilah, niscaya Allah akan meninggikan orang-orang yang beriman di antaramu dan orang-orang yang diberi ilmu pengetahuan beberapa derajat. dan Allah Maha mengetahui apa yang kamu kerjakan".

Dari pandangan itu, dipahami bahwa tugas guru merupakan pewaris Nabi (warasat al anbiya), yang pada hakikatnya mengemban misi rahmatan lil'alamin (membawa rahmat bagi seluruh alam), yakni suatu misi yang mengajak manusia untuk tunduk dan patuh pada hukum-hukum Allah guna memperoleh keselamatan dunia dan akhirat. Kemudian misi ini dikembangkan kepada pembentukan kepribadian yang berjiwa tauhid, kreatif, beramal sholeh dan bermoral tinggi.

Untuk melaksnakan tugas sebagai warasatulanbiya, gur hendaklah bertolak pada amar ma'ruf (memerintah kepada yang baik) yang diimbangi dengan nahi an almunkar (mencegah kemunkaran/kejelekan), menjadikan prinsip tauhid sebagai pusat kegiatan penyebaran misi Iman, Islam dan Ihsan. Dengan demikian, menurut Alghazali, tugas utama guru adalah menyempurnakan, membersihkan dan menyucikan hati manusia untuk mendekatkan diri kepada Allah. Sejalan dengan pendapat ini, An Nahlawi mengatakan bahwa ada dua tugas utama guru, yaitu pertama, fungsi penyucian, yakni berfungsi sebagai pembersih, pemelihara dan pengembang fitrah manusia. Kedua, fungsi pengajaran, yakni menginternalisasikan kepada manusia.

Pendapat lain mengemukakan bahwa fungsi pendidik yaitu, pertama pensucian artinya sebagai pemelihara diri, pengembang serta 
pemeliharaan fitrah manusia, kedua adalah fungsi pengajaran artinya sebagai penyampai ilmu pengetahuan dan berbagai keyakinan kepada manusia agar mereka menerapkan seluruh pengetahuan dalam kehidupan seharihari. Maka dari itu, peran pendidikan sangat berperan penting dalam proses pendidikan, karena dia yang bertanggung jawab dan menentukan arah pendidikan tersebut. Maka, itulah sebabnya Islam sangat menghargai dan menghormati orang-orang yang berilmu pengetahuan dan bertugas sebagai pendidik yang mempunyai tugas yang sangat mulia (Basuki dan Ulum, 2007:881).

Untuk mewujudkan pendidik yang professional sekaligus yang berkompeten dalam pendidikan Islam, didasari dari tuntutan Nabi Saw karena beliau satusatunya pendidik yang paling berhasil dalam rentang waktu yang singkat, sehingga diharapkan dapat mendekatkan realitas pendidik dengan yang ideal (Nabi Saw). Keberhasilan Nabi Saw, sebagai pendidik didahului oleh bekal kepribadian (personality) yang berkualitas unggul ini ditandai dengan kepribadian Rasul yang dijuluki Al-Amin yakni orang yang sangat jujur dan dapat dipercaya, kepedulian Nabi terhadap masalah-masalah sosial religius, serta semangat dan ketajamannya dalamiqro' bismirobbik. Kemudian beliau mampu mempertahankan dan mengembangkan kualitas iman dan amal saleh, berjuang dan bekerja sama menegakkan kebenaran. Berikut ini adalah kompetensi pendidik dan pendidikan Islam:

1. Kompetensi Personal Religius

Kemampuan dasar (kompetensi) yang pertama bagi pendidik adalah menyangkut kepribadian agamis, artinya pada dirinya melekat nilai-nilai lebih yang akan diinternalisasikan kepada peserta didiknya. Misalnya nilai kejujuran, musyawarah, kebersihan, keindahan, kedisiplinan, ketertiban dan sebagainya. Nilai tersebut perlu dimiliki pendidik sehingga akan terjadi transinternalisasi (pemindahan penghayatan nilai-nilai) antara pendidik dan anak didikbaik langsung maupun tidak langsung atau setidak-tidaknya terjadi transaksi (alih tindakan) antara keduanya.

2. Kompetensi Sosial Religius

Kemampuan dasar kedua bagi pendidik adalah menyangkut kepeduliannya terhadap masalah-masalah sosial selaras dengan ajaran Islam. Sikap gotong 
royong, tolong menolong, egalitarian (persamaan derajat antara sesame manusia), sikap toleransi dan sebagainya juga perlu dimiliki oleh pendidik untuk selanjutnya diciptakan dlam suasana pendidikan Islam dalam rangka transinternalisasi sosial atau transaksi sosial antara pendidik dan anak didik.

3. Kompetensi Profesional Religius

Kemampuan dasar yang ketiga ini menyangkut kemampuan untuk menjalankan tugasnya secara professional dlam arti mampu membuat keputusan keahlian atas beragamnya kasus serta mampu mempertanggung jawabkan berdasarkan teori dan wawasan keahliannya dalam perspektif Islam. Kompetensi di atas dapat dijabarkan dalam kompetensi-kompetensi sebagai berikut:

a. Mengetahu hal-hal yang perlu diajarkan, sehingga ia harus belajar dan mencari informasi tentang materi yang diajarkan.

b. Menguasai keseluruhan bahan materi yang akan disampaikan pada akan didiknya.

c. Mempunyai kemampuan menganalisa materi yang diajarkan dan menghubungkannya dengan konteks komponen-komponen secara keseluruhan melalui pola yang diberikan Islam tentang bagaimana cara berpikir (way of thinking) dan cara hidup (way of life) yang perlu dikembangkan melalui proses edukasi.

d. Megamalkan terlebih dahulu informasi yang telah didapat sebelum disajikan kepada anak didiknya (QS. 61:2-3).

e. Mengevaluasi preses dan hasil pendidikan yang sedang dan sudah dilaksanakan (QS.2;31).

f. Memberi hadiah (tabsyir/reward) dan hukuman (tanzir/punishment) sesuai dengan usaha dan upaya yang dicapai anak didik dalam rangka memberikan persuasi dan motivasi dalam proses belajar (QS. 2;119).

g. Memberikan uswatun hasanah dan meningkatkan kualitas dan keprofesionalannya yang mengacu pada futuristic tanpa melupakan peningkatan kesejahteraannya, misalnya; gaji, pangkat, kesehatan, perumahan sehingga pendidik benar-benar berkemampuan tinggi dalam 
transfer of heart, transfer of head, dan transfer of hand kepada anak didik dan lingkungannya.

\section{E. Kesimpulan}

Guru adalah seseorang yang memberikan ilmu pengetahuan kepada anak didiknya dan bertanggung jawab untuk mendidik, mengajar, membimbing, mengarahkan, menilai dan mengevaluasi anak didiknya agar bermanfaat dimasa yang akan datang. Guru profesional yaitu guru yang mampu menerapkan hubungan yang berbentuk multidimensional. Guru yang demikian adalah yang secara internal memiliki empat kompetensi, yaitu: kompetensi pedagogik, kompetensi profesional, kompetensi kepribadian, dan kompetensi sosial.

Perfektif Islam tentang keudukan dan perananan guru adalah memposisikan guru atau pendidik pada kedudukan yang mulia. Para pendidik diposisikan sebagai bapak ruhani (spiritual father) bagi anak didiknya. Ia memberikan santapan ruhani dengan ilmu dan pembinaan akhlak mulia (akhlaqalkarimah) dan meluruskannya.

Untuk mewujudkan pendidik yang professional sekaligus yang berkompeten dalam pendidikan Islam, didasari dari tuntutan Nabi Saw karena beliau satusatunya pendidik yang paling berhasil dalam rentang waktu yang singkat, sehingga diharapkan dapat mendekatkan realitas pendidik dengan yang ideal (Nabi Saw). Berikut ini adalah kompetensi pendidik dan pendidikan Islam : Kompetensi Personal Religius, Kompetensi Sosial Religius dan Kompetensi Profesional Religius

\section{Daftar Pustaka}

Ahmad Tafsir, Dr. 2005. Ilmu Pendidikan dalam Perspektif Islam. Bandung: Remaja Rosdakarya

Daradjat, Zakiah.2012. Ilmu Pendidikan Islam. Jakarta: Bumi Aksara

Djamarah, Syaiful Bahri. 2002. Strategi Belajar Mengajar. Jakarta: Rineka Cipta, Hasan Basri, Drs., 2009. Filsafat Pendidikan Islam. Bandung: Pustaka Setia,

Muhaimin, Suti'ah, Nur Ali. 2008. Paradigma Pendidikan Islam. Bandung: PT. Remaja Rosdakarya

Nurdin, Muhammmad. 2010. Kiat Menjadi Guru Profesional. Yogyakarta: AR. Ruzz Media Group.

Jahiriansyah, Wahyudi dan M. Syukri. 2013. Peran Kepala Sekolah Sebagai Pendidik Dalam Meningkatkan Kompetensi Pedagogik Guru. Jurnal Pendidikan dan Pembelajaran Vol 2, No 10. Diakses dari id.portalgaruda.org pada 4 Oktober 2017. 
Malik, Oemar. 2009. Pendidikan Guru Berdasarkan Pendekatan Kompetensi. Jakarta: PT. Bumi Aksara.

Muhson, Ali. 2004. Meningkatkan Profesionalisme Guru: Sebuah Harapan. Yogyakarta. Jurnal Ekonomi dan Pendidikan. Volume 2, Nomor 1.

Mulyasa, Enco. 2013. Standar Kompetensi dan Sertifikasi Guru. Bandung: PT. Remaja Rosdakarya.

Musfah, Jejen. 2015. Peningkatan Kompetensi Guru melalui Pelatihan dan Sumber Belajar Teori dan Praktik. Jakarta: Prenadamedia Group.

Nursyamsi. 2014. Pengembangan Kepribadian Guru. Padang. Jurnal Al-Ta'lim. Volume 21, Nomor 1.

Rifma. 2013. Problematika Kompetensi Pedagogik Guru Sekolah Dasar. Jurnal Ilmiah Ilmu Pendidikan Vol XIII, No 1. Diakses dari id.portalgaruda.org pada 4 Oktober 2017.

Siswoyo, Dwi. 2013. Ilmu Pendidikan. Yogyakarta: UNY Press.

Undang-Undang Nomer 14 Tahun 2005 